\begin{tabular}{|c|c|c|c|c|c|c|}
\hline \multirow{4}{*}{ Impact Factor: } & ISRA (India) & $=3.117$ & SIS (USA) & $=0.912$ & ICV (Poland) & $=6.630$ \\
\hline & ISI (Dubai, UAF & $=0.829$ & РИНЦ (Russia) & $=0.156$ & PIF (India) & $=1.940$ \\
\hline & GIF (Australia) & $=0.564$ & ESJI (KZ) & $=8.716$ & IBI (India) & $=4.260$ \\
\hline & JIF & $=1.500$ & SJIF (Morocco) & $=5.667$ & OAJI (USA) & $=0.350$ \\
\hline
\end{tabular}

\section{SOI: $1.1 /$ TAS $\quad$ DOI: $10.15863 /$ TAS \\ International Scientific Journal Theoretical \& Applied Science}

p-ISSN: 2308-4944 (print) e-ISSN: 2409-0085 (online)

Year: $2019 \quad$ Issue: $07 \quad$ Volume: 75

Published: $04.07 .2019 \quad$ http://T-Science.org
QR - Issue

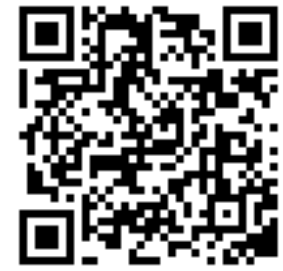

QR - Article

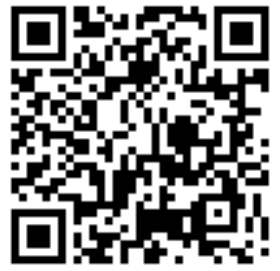

Erkin Ganiev

the Djizakh pedagogical institute Ph.D., Cand.Sci., docent, Chief of the chair "Information technology", Uzbekistan

\title{
FORMATION OF PRESCHOOL EDUCATIONAL INSTITUTIONS AND THEIR MECHANISMS OF MODELLING
}

\begin{abstract}
In article questions of development of national system preschool and vocational training are considered. Last years on strengthening of its legal base complex measures have been taken for development of vocational training, modernization and modernization of educational process, a number of system measures for support of target youth in achievement by them the considerable international both Republican's Olympic Games and competitions has been undertaken. Considering prospects of development of economy and priority problems, of modern technics and technological tendencies introducing modern information-communication technologies on high requirement and related specialties on work preparation of the qualified personnel possessing practical skills and knowing not less two languages. Considering real requirement, offers of the enterprises giving work, coordination of activity of professional colleges on radical improvement of quality of preparation of necessary experts. Formations and even more strengthening of modern material base of professional colleges equipped with school desks based highly effective the education- lab ware, computer technics and innovative technologies, to acceptance of the decree realization of measures of its effective utilization perfection of system of continuous formation and preparation of qualified personnel, is considered attention from the state on questions of an openness of educational services and quality.
\end{abstract}

As a result of national independence, the state is fast becoming a state-of-the-art policy-based approach to completing a full-fledged government policy.

Key words: Education system, innovative development, national education program, continuous formation, strategy of development of republic, preschool education.

Language: English

Citation: Ganiev, E. (2019). Formation of preschool educational institutions and their mechanisms of modelling. ISJ Theoretical \& Applied Science, 07 (75), 5-8.

Soi: http://s-o-i.org/1.1/TAS-07-75-2 Doi: crossef https://dx.doi.org/10.15863/TAS.2019.07.75.2

Classifiers: Education.

\section{Introduction}

For years of independence the national education system and training became one of state policy pressing questions in republic. As a result of realization of the National program of training of the citizens, the Republic of Uzbekistan prepared by the First President of the Republic of Uzbekistan Islam Karimov and the world community, in the country creates unique system of continuous formation.

The president of the Republic of Uzbekistan Shavkat Mirziaev in December, 29th, indicate the reform in the school educations, on January, 25th 2018 said about measures on the further perfection of system of an average special and systems of vocational training on the basis of perfection of system of higher education on a condition and on July, 25th 2018 year strategy of innovative development of Republic Uzbekistan.

\section{Materials and Methods}

The President of Republic Uzbekistan S.M. Mirziaev on February, 7th, 2017 said about movement on strategy of the further development of the Republic of Uzbekistan.

The decree № 4947 from the decision «about the International competitiveness of the country and 


\begin{tabular}{|c|c|c|c|c|c|c|}
\hline \multirow{4}{*}{ Impact Factor: } & ISRA (India) & $=3.117$ & SIS (USA) & $=0.912$ & ICV (Poland) & $=6.630$ \\
\hline & ISI (Dubai, UAE & $=0.829$ & РИНЦ (Russia & $=0.156$ & PIF (India) & $=1.940$ \\
\hline & GIF (Australia) & $=0.564$ & ESJI (KZ) & $=8.716$ & IBI (India) & $=4.260$ \\
\hline & JIF & $=1.500$ & SJIF (Morocco & $=5.667$ & OAJI (USA) & $=0.350$ \\
\hline
\end{tabular}

innovative theoretical the size as the key factor in definition of progress of human reason - the Main objective of strategy of development».

Head Oliy Mazhlis said on December, 22nd, 2017 «Our great descendants of Al-Horezmi, Ibn Sina» allies unfortunately, is not enough attention to a problem of formation of the presented.

The vital value, in connection with 26th anniversary of acceptance of the Constitution of Uzbekistan works on December, 7th, 2018 from achievement, words «Standards of preparation of teachers and training methods in sphere of national education on the basis of the advanced foreign experience».

Possibility of the double should be considered from the point of view of their childhood, children ability of attention to development of all possibilities in our country, many of Biruni, Ibn Sina, Ulugbek.

The decree of the President of Republic of Uzbekistan from September, 30th, 2018 № PC 3955 «About measures on perfection of management by an education system in the future» the Most important criterion in the Road map for the Concept of management of system of continuous formation plays a main role in this life.

We cannot achieve any changes or prosperity without personnel preparation. Preparation of such shots, the healthy and formed generation of the nation begins with preschool education system.

The preschool education system is the basic and most important part of system of continuous formation. On the basis of scientific researches of scientists and experts of $70 \%$ of all information which the person can receive during the life, makes 5 years.

The decision of the Cabinet of Ministers of the Republic of Uzbekistan on September, 30th, 2018 «About measures on the further perfection of preschool education for 2017-2021 years». According to a road map, «Prospect and priorities of modern and innovative technologies in the country of economic development to take into consideration and the experts connected with them with great attention which they need practical skills, and also at least, it is considered to teachers of the qualified foreign languages important.

1. Perfection of a state policy and management in preschool education.

2. Perfection of system of a professional training in preschool education.

3. Perfection of procedure of reception in educational establishment by introduction of the state interactive services.

4. Financial stimulation of workers of the state preschool centers.

5. Perfection of system of medical aid to children in preschool centers regional bodies of public health services.
6. Perfection of system of preparation of a qualitative technique of teaching and didactic materials (including toys and the literature).

7. Perfection of the typical charter of educational institution, and also the typical agreement between preschool centers and parents.

Improvement of infrastructure and material support of the state preschool centers.

8. Perfection of the state preschool education.

9. Complex studying of a condition of preschool educational institutions.

10. Creation of modern preschool centers on the basis of experience of the developed foreign countries.

11. Attraction of preschool educational institutions with attraction of large managing subjects for modern preschool centers and their reconstruction: perfection of an order and norms of state financing of preschool centers and creation and perfection of the transparent centers system of safety.

12. Working out of modern standards of preschool management.

13. To provide qualitative preschool education, to introduce alternative programs of radical improvement of preschool education of children.

14. Increase in quantity of children in preschool educational institutions in countryside.

Strengthening of material base of a control system by preschool education is directed on introduction of modern educational programs and technologies to educational process, and also cardinal preparation of pupils for the future of Turkish Republic, is the most important factor of development of young generation.

In this connection 2017-2018 years in our country creative works are spent many, and on the basis of each decision the accelerated and reliable projects are realized, practical results are reached.

For example, the academician of Academy of Sciences of Uzbekistan Gulamov S.S. advanced and reliable scientific research of idea of "mental education» and «mental medicine» which brings up and develops mental faculties for development of the human capital.

It uses for an optimum solution of a problem with use of innovative methods for definition of the general and additional demand for real teachers and the teachers working in preschool educational institutions.

So, for the purpose of working out of mathematical model of the decision of problems in pedagogical shots at perfection of management by preschool centers, using the methods set forth above, we enter following characteristics.

I-zone Quantity of preschool centers quantity of the skilled teachers working in preschool educational institutions

T-year is planned $\mathrm{Ti}$ - $\mathrm{T} *$ increase $\mathrm{T}$-time 


\begin{tabular}{|c|c|c|c|c|c|c|}
\hline \multirow{4}{*}{ Impact Factor: } & ISRA (India) & $=3.117$ & SIS (USA) & $=0.912$ & ICV (Poland) & $=6.630$ \\
\hline & ISI (Dubai, UAE & $=0.829$ & РИНЦ (Russia & $=0.156$ & PIF (India) & $=1.940$ \\
\hline & GIF (Australia) & $=0.564$ & ESJI (KZ) & $=8.716$ & IBI (India) & $=4.260$ \\
\hline & JIF & $=1.500$ & SJIF (Morocce & $=5.667$ & OAJI (USA) & $=0.350$ \\
\hline
\end{tabular}
centers.

Quantity of the teachers working in IT preschool

Reduction of demand for pedagogical experts in the planned years in preschool centers.

On the basis of resulted above definition we develop mathematical model of a problem.

The formula of calculation of the contribution of pedagogical experts in number of the pedagogical workers working in each of 1000 state and not state preschool centers.

Will be the following [1].

$$
b_{i}=b_{i} 100 / a_{i}
$$

The long-term forecast is based on the plan (for the period from 5 till 25 years) for number of heads of the higher educational institutions preparing pedagogical shots for preschool centers, within 1000 [2].

$$
\mathrm{M}_{\mathrm{i}}=\left(\sum \sum\left(\mathrm{b}_{\mathrm{i}}+\mathrm{b}_{\mathrm{ij}}\right) \mathrm{T}-1000\right) / \sum \sum \mathrm{a}_{\mathrm{ij}}
$$

Proceeding from the formula, the quantity of the pedagogical experts necessary for the prospective look-ahead plan, is defined under the formula, proceeding from requirement of preschool educational institutions for pedagogical experts $[2,3,4$, $5,6,7]$.

$$
\mathrm{Qb}_{\mathrm{i}}=\mathrm{b}_{\mathrm{i}}+\left(\mathrm{b}_{\mathrm{i}}+\mathrm{b}_{\mathrm{iT}}\right)
$$

Now it is possible to define quantity of pedagogical experts which the quantity of preschool pedagogical experts and quantity of the teachers working in preschool centres is necessary to prepare on the basis of a long-term plan of definition of requirement for the qualified pedagogical experts with modern pedagogical and information technology for improvement of preschool educational institutions $[8,9,10]$.

$$
\mathrm{D}_{\mathrm{i}}=\mathrm{L}_{\mathrm{i}}-\mathrm{b}_{\mathrm{i}}
$$

As a whole, important positively to satisfy requirement for pedagogical experts with modern knowledge for education of future intellectually aesthetic and physically developed generation.

It is a multistage problem in which the system of mathematical modeling for definition of the optimum decision with use of uniform network model is used;

That is on the basis of known mathematical instructions on optimization of the scheme of plans of preschool preparation.

Preparation of the qualified pedagogical experts is a key question in perfection of management by preschool education, preparation; retraining and improvement of professional skill of pedagogical shots play an important role in management of school education system.

\section{Conclusion}

As a result of inability to satisfy demand of pedagogical experts for their special requirements for a concrete situation it is not expected that this problem will lead to desirable result as the problem of definition of pedagogical experts is frequently difficult enough for the decision, basically it is based on pedagogical, congenital, socially to define their prospects on the future.

There are some ways to study requirement for pedagogical shots for improvement of management by preschool education, basic of which.

- Knowledge of level of availability of pedagogical experts in preschool educational institutions which is focused on dynamic and statistical factors in comparison with quantity of the formed and skilled experts with modern pedagogical and information technology in educational institutions.

- The extrapolation method is directed on definition of a salary of teachers taking into account long-term calculation on the basis of the innovative plan.

- The organization of additional annual services by the state preschool centers in target and working hours over the installed program (training on care of children and other).

It is offered to raise reception of receipts on pedagogical specialties' in higher educational institutions for preparation of the qualified experts for perfection of management by preschool centers in regions.

Strengthening of material base of 2200 preschool centers for 2017-2021 year to prepare children of 5-6 years for school education that, in turn, will improve preschool education system it is planned to create 6100 short-term groups and to prepare children for preschool education at the age of 3-6 years for preparation of their parents for methodical use.

Execution of the Decree of the President of Republic Uzbekistan №PF-5198 on September, 30th, 2017 «About measures on radical perfection of a control system by preschool education», the further expansion of the state and not state branches, creation of conditions for a healthy competition between them, partner relations, with introduction of new forms of preschool education in Uzbekistan, by means of which intellectual, physical, directed on education.

\section{References:}

1. Ganiev, E., \& Mukhamedov, G.I. (2004, June 24). Mathematical modeling, Accommodation and perfection of Regional and Professional Educational Establishment on the Bases of 


\begin{tabular}{|c|c|c|c|c|c|c|}
\hline \multirow{4}{*}{ Impact Factor: } & ISRA (India) & $=3.117$ & SIS (USA) & $=0.912$ & ICV (Poland) & $=6.630$ \\
\hline & ISI (Dubai, UAE & $=0.829$ & РИНЦ (Russia & $=0.156$ & PIF (India) & $=1.940$ \\
\hline & GIF (Australia) & $=0.564$ & ESJI (KZ) & $=8.716$ & IBI (India) & $=4.260$ \\
\hline & JIF & $=1.500$ & SJIF (Morocce & $=5.667$ & OAJI (USA) & $=0.350$ \\
\hline
\end{tabular}

Multistage System. New Opportunities for Application of Information Technologies for Development of Business, economic Growth, Social Welfare and Education. (pp.65-66). Korea: Yeungnam University Daegu.

2. Ganiev, E. (2012). Optimal placing of a network of comprehensive schools of region. Pedagogical sciences, №3.

3. Ganiev, E. (2018). Mathematical Modeling of the Regional System of Professional Education of the Republic of Uzbekistan. Abusage 3.

4. Ganiev, E., \& Abliakimova, R.I. (2019). Modeling systems on strengthening of educational preparation 57. February, 1-2st, 2019. Moscow: Proceeding of REU after G.V. Plekhanov.

5. Ganiev, E. (2019). Prospects of perfection of managerial process by vocational training system. J. Colloquium-journal, №3 (27).

6. Ganiev, E. (2019, February 25-26). Mathematical modeling of the regional system of professional education of the Republic of Uzbekistan. International correspondence scientific J. "European education and technology".
7. Ganiev, E. (2004). Ways of use of economicmathematical methods in implementation of the state program of perfection of continuous educational system. "New Opportunities for Application of Information Technologies for Development of Business, economic Growth, Social Welfare and Education". (pp.247-248). Korea: Yeungnam University Daegu.

8. Ganiev, E., \& Mo'minov, I. (2004). Using the modern IT. The manual. -"Fan va texnologiya". (p.158). Tashkent.

9. Ganiev, E., \& Eshankulov, K. (2004, June 2-4). Expedient Model of Acceptable Accommodation of Establishments of Continuous Training. // "New Opportunities for Application of Information Technologies for Development of Business, economic Growth, Social Welfare and Education". (pp.85-86). Korea: Yeungnam University Daegu.

10. Jurayev, R., \& Ganiev, E. (2012). Mathematical modeling, accommodations and perfection of regional and professional educational establishments. The Advanced Science open access journal. Tashkent. 